\title{
NOTES ON THE PERFORMANCE AND CULTIVATION OF SOME LESSER KNOWN EASTERN HIMALAYAN PLANTS
}

\author{
Simon CRUtChley
}

\begin{abstract}
Staff from the Royal Botanic Garden Edinburgh have made four expeditions to eastern Nepal and Bhutan during the years 1985-1991. Brief descriptions and notes on observations, performance and cultivation are given for seven species from this region. The species described are Spiraea hemicryptophyta Grierson, Streptopus parasimplex Hara \& Ohashi, Rubus calophyllus C.B.Clarke, Berberis thomsoniana Schneider, Sorbus kurzii (Prain) C.K. Schneider, Gaultheria tricophylla Royle and Theropogon pallidus (Kunth) Maxim.
\end{abstract}

\section{INTRODUCTION}

The eastern Himalaya, which includes Nepal, Sikkim, Bhutan and Arunachal Pradesh (formerly Assam), extends to about $1,500 \mathrm{~km}$ in length and includes approximately 8,000 species of flowering plants. The extraordinary botanic diversity of this region is largely due to its geological history coupled with the infusion of floristic elements from neighbouring territories.

Within the Himalaya, speciation and floristic exchange have been facilitated by mountain building. While mountains act as a corridor for the movement of alpines, they simultaneously limit the spread of tropical species. Great altitudinal variation, ranging from the subtropical lowland terai to the highest mountains in the world, has given rise to contrasts in habitat and climate. High rainfall, which comes in the form of summer monsoons, has also influenced the distribution of the eastern Himalayan flora. This combination of altitudinal and climatic variation has created unique microhabitats in which speciation can occur. Additionally, the close proximity of the eastern Himalaya to south west China, the centre of diversity for many temperate woody genera, has enabled some Chinese species to move westwards, significantly affecting species composition. These factors in combination have played a major role in the evolution of the current eastern Himalayan flora.

The Royal Botanic Garden Edinburgh (RBGE) has had a long association with both the botany and cultivation of plants from the eastern Himalaya. In 2002, the final part of The Flora of Bhutan, (which included also a record of the plants from Sikkim) was published (Grierson \& Long, 1991, 1999, 2001; Noltie, 1994, 2000; Pearce \& Cribb, 2002). The Flora consists of eight separate parts, with the final one dedicated to orchids, the largest and perhaps most spectacular group of plants in 
the region. The Flora was made possible as a result of collections and data gathered from the areas by collectors and, more recently, from collaborative expeditions involving both botanists and horticulturists. These expeditions were particularly fruitful and, from a horticultural perspective, brought into cultivation a number of notable plants, such as Rhododendron kesangiae and Pinus bhutanica.

In recent years, RBGE has mounted several joint botanic and horticultural expeditions to central and eastern. Nepal with four major expeditions taking place during the period 1985-1991. The main purpose of these expeditions was to collect seeds, live plants and herbarium specimens to support the living collections at RBGE and on-going scientific and surveying work. Table 1 lists these expeditions.

\section{Spiraea Hemicryptophyta. Rosaceae}

The genus Spiraea includes some of the most attractive spring and summer flowering plants for the garden. The description that follows is of a species recently introduced into cultivation, that gives an admirable flowering display annually in the Rock Garden at RBGE. Its specific epithet derives from the fact that the annual shoots are killed off by winter frosts and so each year new growth must come from the rhizome below soil level.

Description: rhizomatous shrublet, stems simple (not branched), $20-40 \mathrm{~cm}$ high. Leaves ovate-elliptic, $2.5-4.5 \times 1.7-3 \mathrm{~cm}$ apex acute, base rounded, margin serrate, glabrous, very sparsely pubescent, petiole $2-5 \mathrm{~mm}$ long. Flowers in terminal corymbs, petals white and red, obovate, $2.5-3 \mathrm{~mm}$ long by $2 \mathrm{~mm}$ wide.

As is frequently the case, distinct species can lie in herbaria unrecognised for many years until they are examined critically. Such was the case with $S$. hemicryptophyta which was not recognised as a distinct species until 1987, when preparations for the Rosaceae accounts for the Flora of Bhutan were being prepared by Andrew Grierson. It was he who noticed that a number of specimens were labelled incorrectlyeas $S$. bella Sims. Further investigation led to the recognition of a distinct, widesvidesd, eastern Himalayan species, differing from its closest Himalayan relative $S$. be $S_{i}$ bella its simple branches and broader leaves.

From the specimens cited in the original description it appears to have been been

TABLE 1. RBGE expeditions to eastern Nepal and Bhutan, 1985-1991

\begin{tabular}{|c|c|c|c|c|}
\hline Expedition & Year & Country & Total taxa collected & Total taxa living in 2003 \\
\hline SINCLAIR \& LONG. & 1985 & Bhutan & 166 & 94 \\
\hline $\mathrm{KEKE}^{*}$ & 1989 & Nepal & 353 & 109 \\
\hline CLS** & 1990 & Bhutan & 219 & 95 \\
\hline $\mathrm{EMAK}^{* * *}$ & 1991 & Nepal & 300 & 75 \\
\hline
\end{tabular}

*Edinburgh Kanchenjunga Expedition

** Alan Clark \& Ian Sinclair

*** Edinburgh Makalu Expedition 
collected first as a flowering specimen in Sikkim in 1913 by Phedup with the collection number 1121. This specimen is also cited by Grierson as the holotype (E). Its distribution ranges from Kangrang La in Nepal, through Sikkim, north east Upper Burma, south east Xizang and into Yunnan.

This highly ornamental plant had its first recorded introduction into cultivation from eastern Nepal in 1991 by the Edinburgh Makalu Expedition under the collection numbers 308, 595 and 946. It was found growing at a number of localities between $3,800-4,000 \mathrm{~m}$ generally as a shrublet to $40 \mathrm{~cm}$ high, in rocky outcrops among Rhododendron wightii and $R$. campanulatum woodland. Other associated plants included Berberis spp and Potentilla arbuscula.

Plants raised from seed collected by this expedition are growing successfully in the Rock Garden at RBGE in an open, south facing aspect in a free draining, gritty loam. Flowering generally starts at the beginning of June and lasts for six to eight weeks. The $40 \mathrm{~cm}$ high stems are produced annually from the rhizomatous root system and bear lovely corymbs of red and white flowers. This plant is ideal for the rock garden or at the front of the mixed border where, despite having a rhizomatous root system, it does not spread vigorously, but tends to remain compact. In Edinburgh the annual shoots are killed off by winter frosts causing it to produce new shoots from the rhizomes below the soil level in spring. However, once growth commences no sign of frost damage has been noticed. It does not seem to harbour any problematic pests or diseases.

\section{Streptopus Parasimplex. Convallariaceae}

The genus Streptopus includes a number of handsome rhizomatous perennial herbs found in the northern temperate hemisphere. The genus Streptopus is most closely allied to Polygonatum but differs from that genus in the distinctly bent flower stalk and the perianth segments being fused only at the base. With Polygonatum the flower stalk is not bent and the perianth segments are fused half-way or more. The name Streptopus comes from the Greek words, streptos twisted and pous foot, referring to the flower stalk which is abruptly bent near the middle.

S. parasimplex was described only as recently as 1973 by Japanese botanists from Tokyo University (Hara, 1973). Prior to this new species being described S. simplex was the only known Himalayan representative of the genus. $S$. simplex was described by the 19th century botanist David Don in his work on the flora of Nepal in 1825 . It enjoys a wide distribution occurring from North India into Nepal, Burma and China. S. parasimplex on the other hand has only been recorded from eastern Nepal at present.

Description: rhizomatous perennial herb to $60 \mathrm{~cm}$, stems simple, rarely branched. Leaves alternate, oblong-lanceolate, $3-9 \mathrm{~cm}$ long, $0.7-2.3 \mathrm{~cm}$ wide, apex long acuminate, base amplexicaule, glabrous. Inflorescence borne in the axils of the upper leaves, solitary, peduncle slender, $1.2-5 \mathrm{~cm}$ long, glabrous. Perianth campanulate, whitegreen, tepals purple. Fruit unknown. S. simplex differs from $S$. parasimplex in its 
taller branched stems, broader leaves and the styles which are fused only to the middle, the styles are fused almost to the tip in S. parasimplex. It has been recorded from east Nepal at Topke Gola and Thudam where it is found on dense shady mossy banks under rhododendron and coniferous trees at 3,350-3,500m.

As far as one can tell from cited literature and discussion with expedition members, $S$. parasimplex was first recorded as being introduced by the Kew/Edinburgh Kanchendunga Expedition, collected under the numbers KEKE 363 and 424. The botanic differences between the two species are, however, not obvious and this species may well have been introduced previously under the name $S$. simplex.

Cultivation: seed was sown in the autumn of 1989 in a sand and loam seedling compost and the pots placed outside in a cold frame to germinate. Germination occurred rapidly and by November a number of seedlings had germinated. The seedlings were left in the pot and over wintered in a frost-free glasshouse. They were then potted on during the following spring into a sandy-loam compost and placed into an unheated glasshouse. After a couple of years the plants became a little more established and were potted on into a similar compost and placed in an outside frame. Growth during the next four years was good and the plants were eventually planted into an open leafy soil, in a shady aspect in the garden at Edinburgh. The plants flowered for the first time on 8 July 1993 and, following this, the name was verified by a botanist at Edinburgh. Plants flower regularly in the summer but it is interesting to note that flowering has been recorded as late in the year as October. Unfortunately all the plants in Edinburgh have now died, probably due to overly wet soil during the winter months.

\section{Rubus Calophyllus. Rosaceae}

The notes below describe the discovery, introduction and cultivation of a little known eastern Himalayan Rubus, ideally suited for cultivation in a semi-wild situation.

This handsome shrub was first described in 1885 by Charles Baron Clarke in the Journal of the Linnean Society (Clarke, 1885). In his paper he describes the plants collected during his march from central Assam via Kohima and Muneypore to Cachar in what was then British India, during October and November 1885.

In the journal he describes a number of new species and refers to $R$. calophyllus as a beautiful foliage shrub. The description is accompanied by an attractively drawn plate at the end of the book. The herbarium specimen at RBGE was collected at Jakpho at an altitude of $3,000 \mathrm{~m}$ under the collection number 41351. Interestingly however, there is an earlier collection of this species in the herbarium at Edinburgh made by Colonel Watt in 1882 under his collection number 6152. This was collected from Manipur on the eastern frontier of India. Evidently from his comments inscribed on the label he recognised it as a new species and proposed naming it $R$. dunianus after Lieutenant Dun who accompanied him on the trip. However, whether he saw Clarke's description or never got around to describing it formally is not known. 
Description: arching deciduous shrub $1-3 \mathrm{~m}$ tall. Stems with minute scattered recurved prickles, branchlets white pubescent. Leaves simple, ovate-oblong, $13-18 \times 5-8 \mathrm{~cm}$ apex acuminate, base rounded, lateral veins parallel, closely set, $20-25$, prominent beneath, margin coarsely serrate, with finely pointed teeth, underside white. Flowers in dense rounded, 2-7 flowered axillary panicles, petals deep wine red, obovate, stamens deep red wine. Fruit a cluster of 40, fleshy, one-seeded drupes. Rubus calophyllus occurs in central Bhutan where it is found growing on the margins of wet hemlock and cool broad-leaved forests at an altitude of $2,200-2,900 \mathrm{~m}$.

The nearest ally is probably $R$. lineatus to which it bears resemblance in some aspects of foliage and habit. However, it differs from that species in its simple, not lobed, leaves.

Cultivation: as far as is known $R$. calophyllus was first successfully introduced into western cultivation by the RBGE expedition to Bhutan in 1990, under the CLS number 1675. Seed collected by this expedition was sown in January 1991 into a sand and loam seedling compost and the pots were placed outdoors in a cold frame to germinate. Germination took place on 18 April 1991 and the seedlings were potted on into individual pots for further growing on in an unheated glasshouse.

Once they were large enough, specimens were planted out at Benmore Botanic Garden, Argyll, on the west coast of Scotland. The mild wet conditions seemed ideally suited for this species and it has subsequently formed small impenetrable thickets with the arching stems reaching a metre in length. The attractive red wine coloured flowers appear sporadically throughout mid to late summer. It is the large handsome foliage, with white undersides, that makes this Rubus stand out from other species. Pruning consists only of removing the old flowering stems to ground level in late winter.

\section{Berberis Thomsoniana. Berberidaceae}

This highly ornamental species was first described in 1905 by Camillo Karl Schneider during his work on Berberis, and the description is based upon a collection made in Sikkim by Sir Joseph Dalton Hooker. The name commemorates Hooker's friend and travelling companion Thomas Thomson, who assisted Hooker in his monumental Flora of British India, published between 18.75 and 1897. Thomson, a Scot, studied medicine with Hooker at Glasgow University before travelling to India to become assistant surgeon in the East India Company. He was later to become Superintendent of the Calcutta Botanic Garden.

Description: deciduous shrub to $3 \mathrm{~m}$. Stems strongly grooved, spines in clusters of three. Leaves obovate, $1.5-3.5 \times 0.7-1.5 \mathrm{~cm}$, base attenuate, apex mucronate, margin entire or spinose-dentate. Inflorescence a subumbellate raceme to $4 \mathrm{~cm}$, flowers yellow. Berries ellipsoid, red. It occurs throughout Nepal, Sikkim and Bhutan at altitudes of $3,350-3,960 \mathrm{~m}$. It grows in margins of mixed broadleaf/coniferous woodland. 
B. thomsoniana is similar to the Himalayan B. aristata, but differs most obviously from that species in its strongly grooved stems.

Since its initial discovery it has subsequently been found in Bhutan and Nepal but it has seemingly escaped introduction into cultivation until recent years. However, as a result of RBGE's work in the eastern Himalaya it has now been introduced on three occasions, twice from Bhutan (1984, Sinclair \& Long 4750 \& 4767) and once from Nepal (1991, EMK 583). The Propagation Section at RBGE regularly receives collections of Berberis from the two main centres of distribution for the genus - the Sino-Himalaya and South America - and germination from seed is generally very successful. The seeds of many fleshy fruited genera need to be extracted as the fruit can act as a germination inhibitor. However, this is generally not the case with Berberis. None the less, it is good practice to remove the seed as leaving the fleshy fruit can lead to sporadic germination of seedlings.

Plants have been raised from all three collections and are in cultivation at two of RBGE's Specialist Gardens, Dawyck Botanic Garden and Benmore Botanic Garden, where their abundant flowers and fruit make an attractive display each year.

\section{Sorbus Kurzit. Rosaceae}

Sorbus kurzii, in common with many other rowans, was first described as a Pyrus. It was described in 1904, based upon a collection made in Sikkim. Two years later the famous German botanist Camillo Schneider created a new combination and rightly placed the plant in the genus Sorbus. The specific name is given in honour of W.S. Kurz (1833-78), a German botanist and Curator of the Calcutta Botanic Garden.

Description: small deciduous tree to $4 \mathrm{~m}$; branchlets slender glabrous, stipules small, persistent; leaves pinnate, leaflets four to five pairs, elliptic, margin finely serrated in upper half, $20-30 \times 7-12 \mathrm{~mm}$, rachis grooved; inflorescence in a long narrow corymb, petals white, fruit red/white. Synomyns: $S$. wattii Koehne, Pyrus kurzii Prain. Distribution: Sikkim, eastern Nepal, Bhutan. 3,350-3,650m. Rhododendron forest.

Its nearest ally in the Himalaya is probably $S$. wallichii but it differs from this species in its densely pubescent young shoots and foliage.

S. kurzii was introduced as recently as 1971 when seed was brought back from the Beer, Lancaster and Morris expedition to eastern Nepal, (BL\&M 23, 50). It has since been collected by RBGE staff in the Barun Khola area of eastern Nepal (EMAK 288) an area further west of the BL\&M expedition. Interestingly, the fruits are described as being red on wild trees but in cultivation here at RBGE they are white. The cultivated trees at RGBE however agree in every other respect to the wild S. kurzii. Plants raised from the EMAK trip have made upright shrubs to $1.5 \mathrm{~m}$. in height, planted in rocky, humus rich soil in a south facing aspect. The foliage colours a fiery red in the autumn and provides an attractive contrast to the porcelain white coloured berries. 


\section{GaUltheria Tricophylla. ERICACEAE}

This distinct plant was first described in the beautiful Illustrations of the Botany of the Himalayan Mountains by John Forbes Royle published in 1839. The work was produced in two volumes, one of magnificent colour illustrations, the other of plant descriptions, along with information on the natural history of the Himalaya.

In the written description Royle states that $G$. tricophylla inhabits the high mountains, where the "young, upper parts of the branchlets are furnished with setae, presumably to protect them from the severity of the cold." He also states that the "calyx, adnate to the lower part of the capsule becomes succulent and forms an edible fruit in the month of September."

Description: prostrate creeping shrublet. Leaves opposite, ovate-elliptic, margin cilliate. Flowers campanulate pink/white, calyx lobes triangular. Fruit fleshy skyblue. Distribution: Kashmir to Bhutan, northern Myanmar, western China. 2,700-4,500m. Rocky banks, at side of broadleaf/coniferous forest.

G. tricophylla has since proved to be a widespread species ranging from Kashmir in the western Himalaya, into Nepal, Sikkim, Bhutan, Burma and into south west China. Consequently, it has been introduced into British cultivation on a number of occasions since its first introduction in 1897, when it was received at Kew.

Cultivated material at RBGE has proved to be short-lived, perhaps surviving for the longest period if grown in dry soil in heavy shade.

\section{Theropogon Pallidus. Convallariaceae}

At first glance this attractive garden plant can be easily be mistaken for an Ophiogopgon, with its tufted habit, long, linear leaves and terminal clusters of white flowers. Theropogon pallidus is, however, an interesting close relative of the handsome Ophiopogon and is just as valued in the garden as its larger cousin.

Description: a tufted perennial herb. Leaves linear to $30 \mathrm{~cm}$. (usually much smaller in cultivation), glabrous, glaucuous beneath. Inflorescence a terminal raceme, perianth segments 6, white-pale lilac. Fruit a several-seeded berry. It grows in Nepal, Sikkim, Bhutan and Xizang at 1,800-2,700m on rocky open ground in broadleaf/ coniferous forest.

T. pallidus is a genus of a single species. It is distinguished from its closest relative Ophiopogon in its superior ovary as opposed to the inferior ovary in the much larger genus Ophipogon.

Cultivation: T. pallidus is best cultivated in a shady, moderately dry soil, so long as it does not dry out in summer. It is found from central Nepal eastwards into Sikkim, Bhutan, Myanmar and into Yunnan in south west China where it grows in either open ground amongst rocks, or in shady areas. George Forrest found it several times in Yunnan, although it is not known whether he collected seed. The same can be said of R.E. Cooper, who saw it on a number of occasions in Bhutan and Sikkim. However, the first recorded successful introduction is that by seed sent to Britain by 
Frank Kingdon Ward on his Mt. Victoria expedition of 1956. Plants raised from this collection are still in cultivation at RBGE. A more recent introduction made by former Alpine and Propagation Garden Supervisor George Kirkpatrick from Sikkim is also in cultivation. It forms a charming little plant, coming into flower in midsummer. The white, nodding campanulate flowers last for a number of months.

\section{REFERENCES}

Ahrendt, L. W. A. (1941). Plants new or noteworthy: New deciduous Berberises. Gard. Chron. CIX, 3rd series, 100-101

Ahrent, L. W. A. (1941). A survey of the genus Berberis L. in Asia. J. Bot. British \& Foreign. LXXIX, Special Supplement.

Bean, W. J. (1970). Trees and Shrubs Hardy in the British Isles. Vols. 1-4 \& supplement.

Clarke, C. B. (1876). Botanic notes for Darjeeling to Tonglo. J. Linn. Soc. Bot. 15, $116-159$.

Clarke, C. B. (1885). Botanic notes for Darjeeling to Tonglo and Sandukphoo. J. Linn. Soc. Bot. 21, 384-391.

Grierson, A. J. C. \& Long, D. G. (1983). Flora of Bhutan. 1 (1). Royal Botanic Garden Edinburgh.

Grierson, A. J. C. \& Long, D. G. (1984). Flora of Bhutan. 1 (2). Royal Botanic Garden Edinburgh.

Grierson, A. J. C. \& Long, D. G. (1987). Flora of Bhutan. 1 (3). Royal Botanic Garden Edinburgh.

Grierson, A. J. C. \& Long, D. G. (1991). Flora of Bhutan. 2 (1). Royal Botanic Garden Edinburgh.

Grierson, A. J. C. \& Long, D. G. (1999). Flora of Bhutan. 2 (2). Royal Botanic Garden Edinburgh.

Grierson, A. J. C. \& Long, D. G. (2000). Flora of Bhutan. 2 (3). Royal Botanic Garden Edinburgh.

Ha RA, H. (1973). New or noteworthy flowering plants from the eastern Himalaya (13). $J$. Jap. Bot. 48 (12), 353-369.

Lancaster, R. (1995). A Plantsman in Nepal. Antique Collector's Club, Woodbridge, Suffolk.

Long, D. G. (1984). Notes relating to the Flora of Bhutan : ix Corydalis (Fummariaceae). Notes RBGE. 42 (1): 87-106.

Noltie, H. J. (1994). Flora of Bhutan. 3 (1), Royal Botanic Garden Edinburgh.

Noltie, H. J. (2000). Flora of Bhutan. 3 (2), Royal Botanic Garden Edinburgh.

Pearce, N. R. \& Cribi, P. J. (2002). The Orchids of Bhutan. Flora of Bhutan Vol 3, Part 3. Royal Botanic Garden Edinburgh and Royal Government of Bhutan.

Desmond, R. (1999). Sir Joseph Dalton Hooker, traveller and plant collector. Antique Collector's Club with Royal Botanic Gardens Kew, Woodbridge, Suffolk. 